\title{
The Transversalization of the Gender Perspective in the Educational Curriculum
}

\section{La transversalidad de la perspectiva de género en el currículo educativo}

DOI: $10.46932 / \mathrm{sfjdv} 2 \mathrm{n} 3-044$

Received in: May 1st, 2021

Accepted in: Jun 30th, 2021

\section{MEd. Arely Velasco Miranda}

Master's Degree in Higher Education of Benemérita Universidad Autonoma de Puebla (BUAP), and Bachelor of Modern Languages (BUAP). Intern at the University of California, Santa Barbara, USA (2018). Teacher at Secondary No. 61 of San Martín Texmelucan, Puebla (2015-2019).

E-mail: velascoarelita@gmail.com

\begin{abstract}
Historically, women have experienced exclusion, discrimination and inequitable conditions in education. For this reason, public policies have been promoted in recent decades aimed at mainstreaming the gender perspective in the education system. Key people, such as teachers, managers, students, mothers, fathers and family, play an important role in eliminating discrimination, lack of opportunities and violence in the educational environment. The present work is based on the analysis of the social context of the study region where the research is conducted by participative action-research through a workshop. Those found to have an absence of values and respect for others are identified as having increased school violence, whether physical, psychological and symbolic. Hence the importance of carrying out an analysis of study plans and programs at the secondary level and of teachers and teaching practices that can inform educational intervention proposals to incorporate and carry out in order to transverse the gender perspective in the content of the curriculum, as well as in the daily life of the school.
\end{abstract}

Key words: gender, stereotypes, intersectionality, educative curriculum, transversally.

\section{RESUMEN}

Históricamente, las mujeres han sufrido exclusión, discriminación y condiciones de desigualdad en la educación. Por ello, en las últimas décadas se han promovido políticas públicas orientadas a incorporar la perspectiva de género en el sistema educativo. Las personas clave, como docentes, directivos, estudiantes, madres, padres y familia, juegan un papel importante en la eliminación de la discriminación, la falta de oportunidades y la violencia en el ámbito educativo. El presente trabajo se basa en el análisis del contexto social de la región de estudio donde se realiza la investigación mediante la investigación-acción participativa a través de un taller. Se identifica que los que tienen ausencia de valores y respeto a los demás tienen mayor violencia escolar, ya sea física, psicológica y simbólica. De ahí la importancia de realizar un análisis de los planes y programas de estudio del nivel secundario y de los docentes y las prácticas pedagógicas que puedan informar propuestas de intervención educativa a incorporar y llevar a cabo para transversalizar la perspectiva de género en los contenidos del currículo, así como en la vida cotidiana de la escuela.

Palabras clave: género, estereotipos, interseccionalidad, currículo educativo, transversalidad. 


\section{INTRODUCTION}

Mexico has experienced the effects of neoliberal policies because of the economic crisis of the last four decades, as well as patriarchal cultural practices, which have increased and diversified violence against women. In this situation, the feminist movements since the 1990s have drawn attention to the murders and feminicides against women in Ciudad Juárez. That evidence in Mexico the prevention, punishment and eradication of violence against women is an emerging issue. In the country, Gender Violence Alerts against Women (GVAW) have been decreed from 2015 to 2019. On April 2019, the GVAW was decreed in 50 municipalities of the State of Puebla, among which is the Municipality of San Martín Texmelucan.

Violence against women, also called gender violence, is a priority issue which is taken into account in the National Development Plans in the last three years, through the sectoral plans of the National Institute of Women and the Ministry of Public Education. Public policies have been promoted to mainstream the Gender Perspective in the country's education system. Most of the actions involve teaching staff, managers, students, and parents, who perform an important role to eliminate not only discrimination and lack of opportunities but also violence in the educational field.

This research is based on a regional context in the educational field at Technical Secondary School 61 in San Martin Texmelucan. This work started from the fact of school violence, which can be physical, psychological and symbolic. The purpose is to underline the importance of the analysis of plans and curricula at the secondary level and especially identify which are the teaching practices of teachers to develop intervention proposals in education to incorporate the transversalization of the gender perspective in the curricular contents, as well as in the daily life of the school.

\section{SECTORIAL EDUCATIONAL CONTEXT}

The Gender Atlas prepared by INEGI (2017) presents a set of indicators. According to the statistics of the states of the country, Puebla in the year 2015 ranked first in physical and sexual violence, third in multidimensional poverty and seventh in the employment gap, which reveals that problems prevail that have a long-standing history. In relation to violence against women, Puebla occupies:

[...] the first place nationwide in physical and sexual violence with $9.92 \%$ of the women 15 years and older; also the prevalence of total violence against women aged 15 years or older was $62.83 \%$; 43.3 percent of 15 -year-old women or more actively participate in the economic life of the entity and it is the seventh state with the widest gap in employment at the national level. In relation to poverty, the population ranked third at the national level in multidimensional poverty with $65.44 \%$ (INEGI, 2017). 
The Education Sector Plan 2013-2018 refers to promoting equality between genders in educational institutions, through the educational curriculum, training teaching staff to eliminate gender gaps in each one of the educational systems.

Therefore, it is important to look again at the statistics offered INEGI (2017) for Puebla State, since it had the fifth greatest schooling gap between men and women:

The literacy rate for the population aged 15 to 24,2015 , was $98.03 \%$ for women, $97.84 \%$ for men and the gap was $0.19 \%$; the grade average schooling of women was $8.28 \%$, while men reached the figure of $8.74 \%$ and there was a gap of $0.45 \%$. The literacy rate for the population aged 15 to 24 was $98.03 \%$ in women, 97.84 for men with a gap of $0.19 \%$ (INEGI, 2017).

The educational indicators of the state of Puebla reveal that the state of Puebla is going through a situation that it is necessary to reflect on and investigate in school settings. Therefore, it is important to carry out other actions and interventions in the education system. Due to the situation in the state of Puebla, it was necessary to investigate the context of San Martin Texmelucan, where Technical Secondary School 61 is located. The percentage of educational lag in the municipality in 2010 was $17.1 \%$, with 25,843 inhabitants; while in 2015 , it decreased to 14.4 , with a population of 21,770 (see table 1 ). The city has modern services and all educational levels, from preschool, primary, secondary and high school to the highest level, universities.

Table 1. Educational lag in San Martín Texmelucan, Puebla, 2015

\begin{tabular}{|c|c|c|c|c|c|}
\hline \multicolumn{6}{|c|}{ Educational Lag } \\
\hline $\begin{array}{c}\text { Percentage } \\
2010\end{array}$ & $\begin{array}{c}\text { Percentage } \\
2015\end{array}$ & $\begin{array}{c}\text { People } \\
2010\end{array}$ & $\begin{array}{c}\text { People } \\
2015\end{array}$ & $\begin{array}{c}\text { Deficiencies } \\
\text { on average } \\
2010\end{array}$ & $\begin{array}{c}\text { Deficiencies } \\
\text { on average } \\
2015\end{array}$ \\
\hline 17.1 & 14.4 & 25,843 & 21,770 & 3.0 & 2.5 \\
\hline
\end{tabular}

Source Information: Annual report on the situation of poverty and social lag. INEGI, 2015

In San Martín Texmelucan, there is a high poverty rate educational lag, despite its being an urbanized area. The question is: what is happening in the security context? According to the State Attorney General's Office (SAGO) in 2017, the municipality ranked fifth in the state for the number of registered cases for violation of minors. Five municipalities concentrated $50 \%$ of the 236 reported cases (see table 2). Some of the cases reported in San Martin occurred within an educational institution.

Table 2. Ranking of municipalities with highest rates of rape of underage children

\begin{tabular}{|c|c|}
\hline Puebla & 89 cases \\
\hline Tehuacan & 10 cases \\
\hline Amozoc & 7 cases \\
\hline
\end{tabular}




\begin{tabular}{|c|c|}
\hline San Andrés Cholula & 7 cases \\
\hline San Martin Texmelucan & 6 cases \\
\hline
\end{tabular}

Source Information: Puebla Broader Regional. SAGO, 2017

Gender violence is a priority issue; therefore, action should be taken to guarantee the human rights of women and others. This topic must be dealt with in the field of education. Teachers need to know the social, economic and educational context.

\section{EDUCATION AND CURRICULUM}

This section describes the importance of incorporating gender as a transversal axis in the curriculum, plans and programs of basic education. This represents a challenge for the development of plans and programs of study, since it is complicated for job designers to meet the needs and demands that society demands of them. The inclusion of practices and content aimed at eradicating gender inequality in daily life and school life, in this case, $\mathrm{SEP}^{1}$ is commissioned.

As Palomar, Mora and Vega suggest, this would allow a full life, where individual rights go together with social justice, and they address the differences based on diversity (Palomar, 2005; Mora, 2006; Vega 2007). This means promoting equality between the sexes, where women's rights and men's may have similar conditions to develop their abilities, participation and decision-making processes in different areas of social life.

To achieve the above, it is important that the basic educational actors are sensitized to this problem of gender inequality and they need to interrogate the real context of each of them. The approach should be to consider gender perspective in planning, in decision making, in actions and in all activities that take place in educational institutions.

The curriculum is a keyword, which works as a center within the education system. For Gimeno (2010), the curriculum is "a gateway between foreign culture and society to educational institutions, on one hand the culture of individuals, on the other between society that is today and that will be tomorrow, among the possibilities of knowing, of knowing how to communicate and express oneself in opposition to closure and ignorance"'(Gimeno, 2010, p. 22).

This means the curriculum takes into account a world of practices, pedagogical theories and teaching-learning strategies. In addition, it involves a series of ideologies, social situations, and aims to eradicate the socio-cultural needs that the environment contains. The main objective of a curriculum is to capture an educational concept, which constitutes the teleological framework.

\footnotetext{
${ }^{1}{ }^{1}$ Secretary of Public Education, in Mexico is Secretaria de Educación Publica (SEP). This secretary is which designed the official curriculum and plans.
} 
[...] a large part of the expectations and confidence in the acquisition of the knowledge and skills that every society requires, it specifies the parameters of quality and efficiency that define our academic life today (Aguirre, 2006, p.3).

The school curriculum represents a project that must be explicitly and implicitly concretizes a series of ideological, socio-anthropological, epistemological pedagogical and psychological conceptions, which express the orientation and intentionality of the educational system.

For Casarini, the curriculum proposal includes "From operating the foundation to putting it into practice, supported by an academic, administrative, legal and economic structure" (Casarini, 1999, p.7). The formal curriculum contains the plans and programs that are designed by specialists in pedagogical theories.

\title{
3.1 STRATEGY 2030 TRANSVERSE AXIS PROJECTS
}

Transversal axis projects are fundamental to contribute to the resolution of significant problems in society through education and they must be included in the educational curriculum. Transversal axes in education can be defined as the "globalizing instruments of an interdisciplinary nature that cover the whole of a curricular mesh and all areas of knowledge, disciplines and subjects in order to create favorable learning conditions "(UNESCO, 1996).

Ernesto Yturralde argues:

\begin{abstract}
"Transversality in the educational field is an articulating instrument with the family and society. Currently it is essential for those of us who work in education and the design of instruments for transferring knowledge and the formulation of strategies for the preservation of values, to use the transversal axis to give a comprehensive approach to the curriculum" (Yturralde, 1998).
\end{abstract}

\section{GENDER AND EDUCATION}

This proposal deals with the gender category. Lamas (1996) refers to understanding how the relationship between the sexes, either as a symbolization or a cultural construction regarding the sexes. In other words, the background is found in the philosophical reflections of Simone de Beauvoir, who wrote "The Second Sex" in 1962. She thinks that human characteristics such as "femininity" are acquired by women through a complex social process, instead of deriving naturally from their sex.

On the other hand, Flores (2001) mentions that gender studies understand sex as a socially prescribed system that tries to categorize the social phenomena that guide the different cognitive structures of individuals, since they are in social regulations that establish the differences of each sex and guide the 
inequalities in people's behavior. This means that gender category is not synonymous with women, but socially constructed.

\subsection{GENDER ROLES AND STEREOTYPES}

A stereotype is the attribution by society of similar characteristics to different members of the same group regardless of their individual differences (Unger, 1994). In the same way, Barbera (1998) writes that stereotypes are representations of actual differences and appropriate constructions although partial, they operate as "knowledge schemes" enabling although partial, they operate as "knowledge schemes" enabling easy and efficient processing.

Moreover, INMUJERES (2002), regarding the consideration of gender stereotypes that reflect popular beliefs about activities, attributed according to gender. Likewise, as gender role meaning that is an assigned task. For example, women they take care of the daughters and sons, they make food, and the men do the mechanical work and load heavy things.

The controversy is about the role of teachers to counter gender stereotypes. Some of them argue that stereotypes are a household product, formed before a child starts school and, therefore, schools must remain neutral while they allow children to make their own gender choices (Singh, 1998). Others believes that, challenging stereotyping, teachers offer free children from traditional restrictions. Yeomann (1999) argues that work with texts and readings not traditional stereotypes promote opportunities for debates in the classroom. Francis (2000) suggests that the introduction of these topics in work sessions mixed sex group will minimize counterproductive rivalry between them.

For that reasons discussed above, gender stereotypes perform all of these functions even more consistently and widely than stereotypes over others groups This makes stereotypes resilient to change because the information reveals that they no longer they form a suitable shorthand characterize the group is likely to be ignored, discounted or forgotten (Wigboldus et al., 2003).

\subsection{GENDER PERSPECTIVE IN EDUCATION}

The gender perspective tries, precisely, to break those patterns apart of naturalness, question them and prove that they are the product of a social construction. Therefore, they are transformable. For Sandra Acker (1994) writes how education is an important medium for teaching which has been involved in this social injustice, because it is a feminized science.

A disadvantage situation in the curriculum, according to Spender (1982) is stereotypes in manuals, and material has all been highlighted for contributing to the creation of a hidden gender curriculum differentiated. It means, in the design of the plans and educational programs are an exercise a reproduction 
of gender stereotypes and roles what they do not help to radicalization of these. It directly affects the education system, subsystems, school planning and teaching-learning process.

In that respect, authors as Palomar (2005) considers that gender perspective can be defined as introduction of a particular look at the understanding of social life. Starting the idea that being a man or woman is a cultural and non-biological fact, in order to create those social inequalities based on sex if someone is male / female is built in the social imagination.

Thus, the gender perspective seeks to generate conditions of equality. That is to say, through gender analysis, the aim is to: identify specific needs, interests and problems of men and women, as well as their opportunities in a social particular context.

\section{METHODOLOGY}

For this study was used a qualitative method taking participative action-research in which "Take the gender category in relation to other categories of analysis [...] and it is essential for the analysis and criticism of social and political relations systems" (Delgado, 2012: 202-204). The data was gotten by a training teacher workshop. This investigation was carried out to teachers at school called Technical secondary 61 located in San Martin Texmelucan, Puebla. This workshop was designed on perspective gender.

\subsection{RESEARCH PERSONS}

The subjects of this study are morning shift teachers, which have 19 teachers, 14 women and 5 men. The women represent $69.5 \%$ of the total population (see table 3 ).

Table 3. Total number of teachers by each subject

\begin{tabular}{|l|l|l|l|}
\hline Subjects & $\begin{array}{l}\text { Total number of } \\
\text { teachers }\end{array}$ & Male & Female \\
\hline Spanish & 2 & 0 & 2 \\
\hline Foreign language & 1 & 0 & 1 \\
\hline Maths & 3 & 2 & 1 \\
\hline Sciences & 2 & 1 & 1 \\
\hline Socials & 5 & 0 & 5 \\
\hline Arts & 1 & 0 & 1 \\
\hline Physical education & 1 & 0 & 1 \\
\hline Technology area & 5 & 2 & 3 \\
\hline
\end{tabular}

Information source: Technical Secondary School 61, 2017-2018. 


\section{RESULTS}

It was taken some observation registers in which showed that teachers do not have sensitization in perspective gender. During a teacher's meeting was taken on November $3^{\text {rd }} 2017$, in which exposed some problems about students who did not present and do their homework and projects of class. One female teacher of Spanish subject said, "the problem is because the mothers go to work and they do not pay attention in students' education, mothers must do that". After that opinion all teacher said that they believe the same and the women must not go to work. Another observation register was taken during emergency teacher meeting because it was occurred some situations about female students who promoted sexting, subdirector was worried about that and she said that need some advises or suggestions that help to minimize the happening. Moreover, she mentioned that some female teachers when they know female students "situation said that those students are "putas" " during a class with all students. One male teacher said, "With discipline female students will be conduct better".

From the observation registers, it was identified that the teaching staff reproduces gender roles and stereotypes within the classroom where they do not pay attention about the needs and social problem outside and inside of school.

For those reasons, workshop has a goal to sensitize to teachers about gender, curriculum and transversal projects. It was designed in two sections the first was gender and the second was the curriculum and education. In the first section, activities were formulated regarding differentiating sex and gender, roles and stereotypes and intersectionality. In the second section, it was designed based on defining what are a curriculum and its types and a work gender transversally projects in the institution.

In the first section, some opinions about gender one female participant mentioned, "talking about these types of issues brings problems and I am sure that tomorrow I have the father of family at my door". This participant belongs to the Spanish area and "commented that you need to have a lot of knowledge on the subject, but in a professionalizing way without have to go to the internet". With a higher tone, a teacher contributed that "this type of workshops should be attended by parents, they must be here, and we have the knowledge". It means that between teachers, there is not a together work and opinions in which are afraid to talk about this in their class. Also, the parents do not pay attention to attend these topics in home.

Nevertheless, where are the social problems as poverty, overpopulation, insecurity? How do these directly affect the internal context of an educational institution? The results are, in Puebla it occupies one of the main places of violence against women, poverty, insecurity and giving parity of babies in adolescents between 8-12 years old. (INEGI, 2018). So, why do teachers not want to include the social

\footnotetext{
${ }^{2}$ Bad words in Mexico is used to express who works as a prostitute.
} 
problems in their lesson plan? Because some teachers prefer to stand outside, and they have problems with their values and professional competences. Teachers must have a social commitment and social justice. About professional competences as teacher needs to design their lesson plan includes social context of their institution.

In the second section, it was about curriculum and transversal project in which is only one teacher knew the definitions of curriculum and the majority do not what is. Teachers were asked by the next question how many teachers include gender topics in their subjects. In that part, socials area answered yes, so, it was informed that exist some public policies which mention that teacher have to include gender topics in their lesson plans independent of their subject. Because of Mexico suffers many social problems about unequal opportunities, discrimination, and violence against women, exclusion and reproduction gender roles and stereotypes.

Therefore, teachers have to attend their social context as outside as inside of school. In order to develop social projects have a great impact to reduce that, students are aware as to what is happening around them, and they promote some solutions of that. In the last activity, teachers designed an axis transverse project with gender perspective. They took the social problem occurs in their internal context, where female students leave the school because of being pregnant, so all subjects decided a general product and each one integrate a specific activity since discipline content.

Finally, they said, "this way to work like an institution was great and all persons are included teachers, director, students and parents". However, others said that, "it was difficult because we have a director that do not help us" "other teachers do not have the commitment to work together and they are irresponsible people". Teachers are aware about the lack of values in their coworkers and they do not want to do anything about it. The public policies exist but what does occur with that? This type of work transverse axis is a way to work as integrate way in which all community of school must work together to get a better social context.

\section{CONCLUSION}

As a conclusion, result important to take into account that the gender category helped to visualize the relationships and the construction of sociocultural difference and understand why inequalities social, economic, political, educational, etc., throughout history they have reproduced asymmetries, inequity and hierarchies of power between men and women both in the world Public as private.

Furthermore, it was identified that the teachers reproduce gender roles and stereotypes in the classroom from the hidden curriculum, and omit the real curriculum where you work to develop their lesson plans. Therefore, it does not consider the social situations that exist in context because it does not 
identify or become aware of the patriarchal culture. How it dominates its, teachers do not question themselves, much less a transformation of their educational and personal practices in the classroom.

During the workshop, teachers argued that they are aware that there is a situation of inequality around the division of roles and gender stereotypes, and this produced a debate giving opinions from their experiences and experiences. Thus, Gimeno supports this, who affirms that the experience lived can be a way teaching. That is, teachers carry out this teaching-learning process from of experience, beliefs and ideologies the hidden curriculum that formal.

In addition, teachers argued that parents are important actors in this teaching process; however, most of them have abandoned their daughters and sons in their educational training, limiting the achievement of expected learning. Therefore, it is necessary to take actions where they participate more in the process of teaching their children

For the above reasons, it is necessary to involve students, parents, teachers, executives and community proposes work for projects on transversally issues, where there is a joint articulation in the realization of these, taking in the situation sociocultural, economic and educational of their community, school and family environment.

In this sense, gender mainstreaming is considered as the introduction of a particular look at the understanding of social life, based on the idea that being a man or a woman is a patriarchal sociocultural construct that has reproduced gender inequalities, male / female binarisms in the social imaginary.

A transversal curriculum with a gender perspective seeks to generate conditions of equality, that is, it is intended to: identify the specific needs, interests and problems of Men and women, as well as their opportunities. An education with a gender perspective it is a fundamental intervention, to influence the sensitization of the educational community (teachers-students-managers) to eradicate practices that reproduce inequities not only in the construction of knowledge but also in the daily life of human beings.

Therefore, it is important to use the gender perspective in planning, execution, monitoring and evaluation of all our educational and daily work. The training of professional competences should be promoted to allow teachers develop a critical, analytical and reflective thinking to act before the social context and design social-educational projects to encourage in their students' knowledge, skills and attitudes towards society. It is necessary to take a look at normal that are responsible for the training of teachers, who must integrate into their formal curriculum teach under professional competencies and project design with themes of transverse axis.

\section{REFERENCES}


Acevedo Huerta, E. (2010). "El curriculum oculto en las enseñanzas formales. Aspectos menos visibles a tener en cuenta en una educación no sexista”, en Temas para la educación. Revista de educación para profesionales de la educación. N. 11, noviembre, Andalucía: Federación de Enseñanza. https://www.feandalucia.ccoo.es/docu/p5sd7590.pdf

Acker, S. (1994). Género y educación, reflexiones sociológicas sobre las mujeres, la enseñanza y el feminismo. Madrid: España: Narcea.

Aguirre, María. (2006). "El currículum escolar, invención de la modernidad". Revista perspectivas docentes 25. Acotaciones. México. Disponible en: http://www.profesaulosuna.com/data/files/EDUCACION/TEORIA\%20Y\%20DISE\%D1O\%20CURRIC ULAR/CURRICULO/HILDA\%20TABA/perspectivas25.pdf

Alexander MJ, Mohanty CT. (1997). Introduction: genealogies, legacies, ovements. In Feminist Genealogies, Colonial Legacies, Democratic Futures, ed. MJ Alexander, CT Mohanty, pp. xiii-xlii. New York: Routledge

Beauvoir S. 2011 (1949). The Second Sex. Transl. C Borde, S Malovany- havallier. New York: Vintage Books. From French.

Belausteguigoitia, M. y Mingo, A. (1999). Géneros prófugos, feminismo y educación. Paidós: México.

Bendl, R. \& Schmidt, A. (2010). From glass ceilings to firewalls: Different metaphors for describing discrimination. Gender, Work and Organization, 17(5), 612-634.

Casarini, M. (1999). Teoría y diseño curricular. México. Trillas.

Collins, P. H. (2000). Black feminist thought: Knowledge, consciousness, and the politics of empowerment (2nd ed.). NY: Routledge.

Commeyras et al. (1997). Questions children want to discuss about literature: What teachers and students learned in a second-grade classroom. Research report no. 47. Athens, GA: National Reading Research Center.

Consejo Nacional de Fomento Educativo [CONAFE], (2004). Equidad. Conceptos.México: CONAFE. Recuperado de http://www.conafe.edu.mx/Equidad3/conceptos.html, el día 15 de abril del 2018.

Crenshaw, K. (2005). Mapping the Margins: Intersectionality, Identity Politics, and Violence against Women of Color (1994). In R. K. Bergen, J. L. Edleson, \& C. M. Renzetti, Violence against women: Classic papers (pp. 282-313). Auckland, New Zealand: Pearson Education New Zealand.

Darsø, L., (2011). Innovationspaedagogik:kunsten at fremelske innovationskompetence. Frederiksberg: Samfundslitteratur.

Delgado, María de los Angeles. (2000). Antropología educativa, gestión cooperativa del conocimiento y desarrollo humano sustentable. International Journal of Developmental and Educational Psychology [en linea]. 2(1), 137-149[fecha de Consulta 7 de julio de 2019]. ISSN: 0214-9877. Disponible en: http://www.redalyc.org/articulo.oa?id=349851784013 
Elliot, J. (1991). Action Research for educational Change. Milton Keynes, Open University Press. España: Morata.

Gimeno, J. (1994). El curriculum: una reflexión sobre la práctica. Madrid: Morata.

Gimeno, J. (2010). ¿Qué significa el currículum? (adelanto). Sinéctica, (34), 11-43. Recuperado en 02 de agosto de 2019, de http://www.scielo.org.mx/scielo.php?script=sci_arttext\&pid=S1665$109 X 2010000100009 \& \operatorname{lng}=$ es \& $\operatorname{lng}=$ es.

Giroux, H. (1999). La educación, la universidad y la sociedad: el vínculo crítico, I edicions de la Universite de Barcelona, España.

Guzmán, V. (2012). Teoría Curricular. RED TERCER MILENIO S.C. México: Red Tercer Milenio.

INEGI (2017). Atlas de género. México: INEGI. http://gaia.inegi.org.mx/atlas_genero/ Consultado el 02 de diciembre de 2018.

INEGI (2017). Encuesta nacional sobre la Dinámica de las Relaciones en los Hogares (ENDIREH) 2016. México:

INEGI. https://www.inegi.org.mx/contenidos/programas/endireh/2016/doc/endireh2016_presentacion_ejecutiva. pdf

INEGI, (2015). Encuesta Intercensal 2015. México: INEGI http://www.coteigep.puebla.gob.mx/est231.php?muni=21169\#TABLA!A4, recuperado el día 2 de septiembre del 2017, 18:34 hrs.

INMUJERES, (2002) Compendio de leyes sobre los derechos de la mujer, INAM, Honduras.

INMUJERES, (2015). Informe de Resultados octubre-diciembre 2015. México: INAM.

Lamas, M. (1986). "La antropología feminista de la categoría de género", Nueva antropología. Estudios sobre la mujer: problemas teóricos 30, Ludka de Gortari (coord.), CONACYT/UAM.

Mohanty CT. (2003). Feminism Without Borders: Decolonizing Theory, Practicing Solidarity. Durham, NC: Duke

Mora, L. (2006). Igualdad y equidad de género: aproximación teóricoconceptual, vol. I, UNFPA, 2006, 143 pp. Disponible en http://www.redalyc.org/pdf/270/27022351003.pdf

Palomar, C. (2006). "La política de género en la educación superior”, en La Ventana, 21, México, 2005, pp. 7-43. Fecha de acceso, 17 de octubre de 2018. Disponible en http://148.202.18.157/sitios/publicacionesite/pperiod/laventan/Ventana21/7-43.pdf

Perrenoud, P. (2000). Construir competencias, diez nuevas competencias para enseñar. Berne. Lang. PERRET-CLERMOND, A.N.; NICOLET, M. (dirs.).

Roblin, J. (2006) “Transversalizar el enfoque de género en la educación superior: empezar haciendo", en Boletín Digital, 115, Instituto Internacional para la Educación Superior en América Latina y el Caribe (IESALC)/UNESCO, 2006. Fecha de acceso, 5 de octubre de 2006. Disponible en www.iesalc.unesco.org.ve/.../bolivia/Viceministerio_Corregido2.pdf 
Scott, Joan. (1986). El género: una categoría útil para el análisis histórico. American Historical review, New York, USA.

SEP. (2011). Planes y programas. Gobierno Federal, México: SEP.

SEP, (2017). Planes y programas. Gobierno Federal, México: SEP.

SESNSP. (2017). Incidencia Delictiva del Fuero Común 2017 Instrumento para el Registro, Clasificación y Reporte de Delitos y las Víctimas CNSP/38/15. Disponible en: http://secretariadoejecutivo.gob.mx/docs/pdfs/nueva-metodologia/CNSP-Delitos-2017.pdf

Singh (1998). The Academy of Management Review 23(4) - October 1998 with 17,170 Reads DOI: $10.2307 / 259056$

UNESCO (2015). Informe de la UNESCO 2014 sobre la Igualdad de Género. Patrimonio y creatividad. Argentina: UNESCO.

Culture/flipbook/es/mobile/index.html http://www.unesco.org/culture/Gender-Equality-and-

UNESCO (2015). Reporte global sobre equidad de género y cultura del Consejo Nacional para la Cultura $y$ las Artes (CONACULTA). Unesco. http://www.unesco.org/new/fileadmin/MULTIMEDIA/HQ/CLT/pdf/Mexico_UNESCO_Questionnaire_ on_Gender_Equality_and_Cultu.pdf

Unger, R. (1994). Los reflejos imperfectos de la realidad: la psicología construye roles sexuales. Barcelona: Univ. Press.

Verger, Antoni y Xavier Bonal (2011). "La estrategia educativa 2020 o las limitaciones del Banco Mundial para promover el "aprendizaje para todos", en Educação \& Sociedade, Campinas SP: Centro de Estudos Educação e Sociedade (Cedes), vol.32, núm. 117, pp. 911-932.

Wakkary, R., (2007). A participatory design understanding of interaction design. Science of Design Workshop. San Jose: CHI.

Wigboldus et al., (2003). What do new views of knowledge and thinking have to say about research on teacher learning? Educational Researcher, 29 (1), pp. 4-1 